\title{
HONORÁRIOS ADVOCATÍCIOS NA TUTELA PROVISÓRIA
}

\section{DEFEAT FEES IN PROVISIONAL REMEDY ATTORNEYS'FEES BORNE BY THE DEFEATED PARTY IN PROVISIONAL GUARDIANSHIP \\ HONORARIOS DE ABOGADOS EN LA TUTELA PROVISIONAL}

Silas Silva Santos ${ }^{1}$

\section{Francislaine de Almeida Coimbra Strasser ${ }^{2}$}

\section{Licença CC BY:}

Artigo distribuído sob os termos Creative Commons, permite uso e distribuição irrestrita em qualquer meio desde que o autor credite a fonte original.
Resumo: O texto aborda a possível incidência de honorários advocatícios sucumbenciais no âmbito da tutela provisória, tal como regulada pelo Novo Código de Processo Civil. Defende-se que, em certos casos, o regime da tutela provisória atua como mero fator de mensuração dos honorários advocatícios fixados na sentença, ao passo que, em outros casos, o instituto da tutela provisória faz surgir, por si só, a obrigação de pagar honorários advocatícios de sucumbência.

Palavras-chave: Honorários advocatícios. Sucumbência. Tutela provisória. Novo Código de Processo Civil brasileiro.

Abstract: The text addresses the possible incidence of attorneys' fees borne by the defeated party within the scope of provisional guardianship, as regulated by the new Code of Civil Procedure. It argues that in certain cases, the system of provisional guardianship acts as a mere factor of measurement of the attorneys' fees established in the sentence, while in other cases, the institute of provisional guardianship creates, in itself, the obligation for the defeated party to pay attorneys' fees.

Key-words: Attorney's fees borne by the defeated party. Provisional remedy. New Brazilian Code of Civil Procedure.

1 Doutor e mestre em Direito Processual Civil pela USP. Professor nos cursos de graduação e de pós-graduação stricto sensu da Unoeste de Presidente Prudente. Coordenador do Grupo de Estudos "Acesso à justiça, inovação e sustentabilidade”, da Unoeste. Juiz de Direito em Presidente Prudente/SP, Brasil. E-mail: silas@unoeste.br.

2 Doutoranda em Função Social no Direito Constitucional na Fadisp/SP. Mestre em Direito Constitucional e Sistemas de Garantias e Inclusão Social pela ITE - Bauru/SP. Professora nos cursos de graduação e de pós-graduação lato sensu da Unoeste de Presidente Prudente/SP. Integrante do Grupo de Estudos "Acesso à justiça, inovação e sustentabilidade", da Unoeste. Advogada em Presidente Prudente/SP, Brasil. E-mail: fran_coimbra_@hotmail. com. 
Resumen: El texto enfoca la posible incidencia de honorarios de abogados que sucumbe en el contexto de medidas provisionales, tal como lo regula el Nuevo Código de Proceso Civil. Se defiende que, en ciertos casos, el régimen de la tutela provisional actua como un mero factor de medición de los honorarios de abogados fijados en la sentencia, mientras que, en otros casos, el instituto de la tutela provisional da lugar, por sí misma, a la obligación de pagar los honorarios del abogado sucumbido.

Palabras clave: Honorarios de abogados. Sucumbir. Tutela provisional. Nuevo Código de Proceso Civil brasileño.

\section{INTRODUÇÃO}

Não há dúvidas de que os honorários advocatícios constituem assunto da mais alta relevância prática, haja vista que, nos termos do art. 85, caput, do Código de Processo Civil (CPC), a sentença condenará o vencido a pagar honorários ao advogado do vencedor. Logo, todas as vezes em que se depara com as noções de vencido e de vencedor, haverá espaço para discutir honorários advocatícios.

Em acréscimo, o $\S 1^{\circ}$ do art. 85 do CPC esclarece que são devidos honorários advocatícios na reconvenção, no cumprimento de sentença, provisório ou definitivo, na execução, resistida ou não, e nos recursos interpostos, cumulativamente.

Para as hipóteses de desistência, renúncia ou reconhecimento da procedência do pedido, os honorários advocatícios são devidos pela parte que desistiu, renunciou ou reconheceu, tal como estabelece o art. 90, caput, do CPC. Nos casos de perda do objeto da demanda (falta de interesse de agir superveniente), os honorários são devidos por quem deu causa ao processo (art. 85, § 10, do CPC).

Mesmo fora da Seção III do Capítulo II do Livro III da Parte Geral do CPC, o legislador ainda trata do assunto dos honorários advocatícios, como se dá, exemplificativamente, na ação monitória (art. 701, caput), no cumprimento de sentença (art. 523, $\S 1^{\circ}$ ) e na execução de títulos extrajudiciais (art. 827, caput e $\S \S 1^{\circ}$ e $2^{\circ}$ ).

Percebe-se, pois, com facilidade, que o assunto é amplo e impregnado de relevância prática, circunstância que, por si só, já revelaria a necessidade de renovadas investigações acadêmicas.

Entretanto, quando se voltam os olhos para a tutela provisória, tal como regulada nos arts. 294 et seq. do CPC, e seu possível entrelaçamento com o tema dos honorários advocatícios, constata-se um silêncio do legislador, o que é outro problema que merece atenção.

As percepções hauridas do regramento do CPC/73, que ainda ecoam de alguma forma no inconsciente coletivo nesses parcos cinco anos de vigência do CPC/2015, igualmente embaçam a visão da realidade e dificultam a construção de modelos interpretativos condizentes com o sistema inaugurado pela nova legislação processual codificada. 
Diante disso, este artigo propõe-se a analisar a legislação em vigor, discernir o modelo atual de tutela provisória e promover o diálogo, se for possível, entre os honorários advocatícios sucumbenciais e a tutela provisória, tudo com a finalidade de construir modelos interpretativos que se ajustem à realidade normativa atual.

Com isso, pretende-se contribuir para a formação de uma compreensão segura do enfrentamento de questões práticas que desafiam o dia a dia do contencioso cível. É claro que isso se faz sem pretensão de esgotamento, pois as construções acadêmicas nem sempre alcançam a velocidade com que as vicissitudes da realidade se apresentam ao intérprete e aplicador do direito.

Para alcançar os objetivos desejados, aplicam-se os métodos indutivo e dedutivo, sem prejuízo de, às vezes, adotar-se discurso dialético. A pesquisa é do tipo aplicada, qualitativa, jurídicoexploratória e bibliográfica. Todos os textos legais citados, quando não acompanhados de alguma referência específica, dizem respeito ao Código de Processo Civil de 2015.

\section{O REGIME FINANCEIRO DO PROCESSO}

A atividade jurisdicional, apreciada de certo ângulo, constitui serviço público oneroso, razão pela qual o interessado no acesso à justiça haverá de arcar com os custos financeiros dessa sua investida. Muito embora a Constituição Federal garanta o acesso à ordem jurídica justa, mediante o exercício do direito de ação (art. 50, XXXV), o efetivo exercício desse direito custa dinheiro. ${ }^{3}$

Evidentemente que a necessidade de uma contraprestação financeira não pode ser erigida à condição de óbice intransponível para o acesso ao sistema de justiça, motivo por que a mesma Constituição Federal estabelece a gratuidade do serviço judiciário para aqueles que comprovarem insuficiência financeira (art. 50, LXXIV). ${ }^{4}$ Com isso, o Estado garante a universalização da jurisdição, ${ }^{5}$ condição indeclinável para que se viva o Estado democrático de direito. Afora os casos de concessão de gratuidade processual, incumbe à parte interessada prover as despesas dos atos que realizar ou requerer, antecipando-Ihes o pagamento, do início ao fim do processo (art. 82, caput, do CPC). ${ }^{6}$

Nesse passo, antes de prosseguir, é indispensável compreender as noções de custas processuais, despesas processuais e honorários advocatícios, uma vez que a legislação efetivamente as diferencia. Realmente, ao tratar da gratuidade processual, o CPC estabelece que a pessoa natural ou jurídica,

3 Na Itália, por exemplo, o sistema também funciona assim, conforme esclarece a doutrina: "Il processo ha un custo. Costo di organizzazione delle strutture materiali e personali che lo Stato deve apprestare, costo che le parti devono sopportare per agire e difendersi concretamente nel giudizio" (PROTO PISANI, Andrea. Lezioni di diritto processuale civile. 5. ed. Napoli: Jovene, 2006, p. 312).

4 No CPC, as regras sobre gratuidade processual estão previstas nos arts. 98 a 102. Para aprofundamentos nesse tema, consulte-se: COSTA NETO, José Wellington Bezerra da. Assistência judiciária gratuita: acesso à justiça e carência econômica. Brasília: Gazeta Jurídica, 2013, passim).

5 DINAMARCO, Cândido Rangel. Universalizar a tutela jurisdicional. In: DINAMARCO, C. R. Fundamentos do processo civil moderno. 6. ed. São Paulo: Malheiros, 2010, p. 429-431.

6 O sistema italiano também adota o ônus da antecipação das despesas: "ogni parte deve, se vuole inoltrarsi nella procedura, sopportare le spese degli atti che compie e di quelli che chiede" (LA CHINA, Sergio. Manuale di diritto processuale civile. Vol. I. Milano: Giuffrè, 2003, p. 190). 


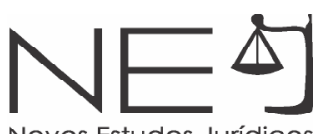

brasileira ou estrangeira, com insuficiência de recursos para pagar custas, despesas processuais e honorários advocatícios, tem direito à gratuidade da justiça (art. 98, caput, do CPC).

O serviço judiciário amplamente considerado, só pelo fato de ser disponibilizado àquele que concretamente exerce o direito de ação, deve ser remunerado mediante o pagamento de custas processuais, que nada mais são do que uma espécie de tributo, mais precisamente de uma taxajudiciária.

No Estado de São Paulo, por exemplo, a taxa judiciária tem por fato gerador a prestação de serviços de natureza forense, devida pelas partes ao Estado, nas ações de conhecimento, na execução, nas ações cautelares, nos procedimentos de jurisdição voluntária e nos recursos (art. $1^{\circ}$ da Lei Estadual no 11.608/2003). Na Justiça Federal, diversamente, o regime das custas devidas à União é disciplinado pela Lei Federal n 9.289/96.

Todavia a taxa judiciária não é capaz de remunerar todo o serviço judiciário, porquanto existem atos específicos no arco procedimental que precisam ser pagos separada e isoladamente. É nesse sentido que o CPC, no já citado art. 82, preconiza que as partes devem prover as despesas dos atos que realizarem ou requererem no processo. Ou seja, são serviços atrelados ao processo que, ex vi legis, não são custeados somente pelo pagamento da taxa judiciária.

Na Justiça Comum do Estado de São Paulo, por exemplo, a Lei Estadual no 11.608/2003 expressamente dispõe que na taxa judiciária não se incluem as despesas com publicações de editais, com o porte de remessa e de retorno dos autos, no caso de recurso, nem as despesas com citações e intimações (art. $2^{\circ}$, parágrafo único, I a III).

Então, além de a parte ter que pagar a taxa judiciária em razão do simples ajuizamento da demanda, haverá de arcar com as despesas para citação, publicação dos editais, intimação de testemunhas etc.

É no contexto das despesas processuais, por exemplo, que o CPC dispõe incumbir ao autor adiantar as despesas relativas a ato cuja realização o juiz determinar de ofício ou a requerimento do Ministério Público, quando a intervenção deste ocorrer como fiscal da ordem jurídica (art. 82, $\S 1^{\circ}$, do CPC). Em tom pedagógico, o CPC estabelece que as despesas processuais abrangem as custas ${ }^{7}$ dos atos processuais, a indenização de viagem, a remuneração do assistente técnico e a diária de testemunha (art. 84).

7 A expressão custas não está, nesse ponto, no seu sentido técnico, mas no seu sentido amplo, a indicar "gastos". Nem sempre a legislação emprega a linguagem técnica adequada. Apesar disso, incumbe ao intérprete e aplicador do direito processual discernir os espaços reservados para as custas e para as despesas processuais. Tanto é verdade que o parcelamento a que alude o art. $98, \S 6^{\circ}$, do CPC só está autorizado quanto às despesas processuais, sendo inviável - porquanto não previsto na lei - a concessão de parcelamento de custas processuais (taxa judiciária). 
Ainda no que se refere ao adiantamento de despesas, cada parte adiantará a remuneração do assistente técnico que houver indicado, mas a do perito será adiantada pela parte que houver requerido a perícia ou rateada, quando a perícia for determinada de ofício ou requerida por ambas as partes (art. 95, caput, do CPC).

As despesas dos atos processuais praticados a requerimento da Fazenda Pública, do Ministério Público ou da Defensoria Pública serão pagas ao final pelo vencido. Isso não significa, porém, que esses entes não devam antecipar o custeio das despesas dos atos por eles requeridos, consoante a orientação jurisprudencial que se cristalizou nos verbetes 190 e 232 da súmula do Superior Tribunal de Justiça (STJ). ${ }^{8}$ Independentemente de quem as tenha antecipado, certo é que as despesas processuais serão reembolsadas pela parte que sucumbir no processo, o que implica dizer que a disciplina da antecipação das despesas tem natureza provisória. ${ }^{9}$ De fato, a sentença condenará o vencido a pagar ao vencedor as despesas que antecipou, conforme expressa orientação do art. $82, \S 2^{\circ}$, do CPC, mesmo porque "a atuação da lei não deve representar uma diminuição patrimonial para a parte a cujo favor se efetiva". ${ }^{10}$

Muito embora o texto da lei refira-se apenas à sentença, dúvidas não pairam de que, em certas decisões interlocutórias, haverá a condenação do vencido a pagar as despesas processuais antecipadas pela parte adversa, tal como se dá, exemplificativamente, na decisão que autoriza a substituição de sujeitos no polo passivo (art. 338, parágrafo único, do CPC), na decisão que encerra a liquidação de sentença ${ }^{11}$ e na que decide a impugnação ao cumprimento de sentença. ${ }^{12}$

Vale acrescentar que não só as partes (em sentido amplo) ficam submetidas ao pagamento de despesas processuais, já que os auxiliares da justiça e o próprio juiz arcarão com as despesas dos atos cujo adiamento ou repetição tenha sido causado, sem justo motivo, por eles (art. 93, do CPC).

Questão particular e de suma importância, que se insere no espectro amplo do regime financeiro do processo, diz respeito às sanções pecuniárias originadas no e por causa do processo.

A litigância de má-fé, por exemplo, enseja a fixação pelo juiz, de ofício ou a requerimento, de multa que varia de $1 \%$ a $10 \%$ do valor corrigido da causa (art. 81, caput, do CPC), revertida em benefício da parte contrária (art. 96, do CPC).

8 Súmula $n^{\circ}$ 190/STJ: "Na execução fiscal, processada perante a Justiça Estadual, cumpre à Fazenda Pública antecipar o numerário destinado ao custeio das despesas com o transporte dos oficiais de justiça". Súmula n $232 /$ STJ: "A Fazenda Pública, quando parte no processo, fica sujeita à exigência do depósito prévio dos honorários do perito". No plano dos chamados processos coletivos, especialmente quando movidos pelo Ministério Público, sugere-se a leitura de artigo da lavra de Ricardo de Barros Leonel (Ministério Público e despesas processuais no novo Código de Processo Civil. Revista de processo, São Paulo, ano 40, v. 249, p. 173-185, nov. /2015).

$9 \quad$ PROTO PISANI, Andrea. Lezioni di diritto processuale civile, cit., p. 312.

10 CHIOVENDA, Giuseppe. Instituições de direito processual civil. 3. ed. Vol. III. Trad. J. Guimarães Menegale. São Paulo: Saraiva, 1969, § 74, n. 381, p. 207.

11 Basta supor que tenha havido prova pericial no âmbito da liquidação, por exemplo.

12 Imagine-se que, por algum motivo, tenha sido necessária a oitiva de testemunhas, com despesas destinadas à sua intimação. 
Na execução, a prática de algum dos atos previstos no rol do art. 774 do CPC enseja a fixação de multa não superior a $20 \%$ do valor atualizado do débito, a qual será revertida em proveito do exequente (parágrafo único do art. 774 do CPC). Ainda na seara recursal, existe a previsão de multa quando os embargos de declaração são manifestamente protelatórios (art. 1.026, § $2^{\circ}$, do CPC).

Seguindo a ordem de exposição até aqui percorrida, os honorários advocatícios sucumbenciais fechariam o cenário desse regime financeiro do processo. Mas, em razão dos objetivos traçados para este trabalho, o tema dos honorários advocatícios será abordado adiante, com mais detença.

\section{HONORÁRIOS ADVOCATÍCIOS: ASPECTOS GERAIS}

Como já visto, no emaranhado de situações inerentes ao regime financeiro do processo civil, insere-se o tema dos honorários advocatícios de sucumbência. Isso porque o custo final do processo atribui-se ao vencido, porquanto a sentença o condenará a pagar as despesas que o vencedor antecipou (art. 82, § 20, do CPC) e os honorários do advogado deste (art. 85, caput, do CPC). ${ }^{13}$ Trata-se de obrigação processual, com atribuição de direito subjetivo a quem o pagamento seja devido, tanto assim que tal obrigação pode ser exigida na via executiva. ${ }^{14}$ Ao vencido atribuemse as consequências da sucumbência. Esse critério serve apenas como indicativo do princípio que, verdadeiramente, preside o tema do custo final do processo. É que, a rigor, o sistema trabalha com a noção de causalidade, da qual a sucumbência constitui mero indicador. "Responde pelo custo do processo aquele que haja dado causa a ele, seja ao propor demanda inadmissível ou sem ter razão, seja obrigando quem tem razão a vir a juízo para obter ou manter aquilo a que já tinha direito". 15

Constatação eloquente dessa ideia está na redação do art. 85, § 10, do CPC, segundo o qual, havendo perda do objeto, os honorários advocatícios serão devidos pela parte que deu causa ao processo. Nessa hipótese, não haverá as figuras de vencido e de vencedor; mesmo assim haverá condenação de uma das partes a pagar o custo final do processo.

Semelhantemente, nos embargos de terceiro, quem deu causa à constrição indevida deve arcar com os honorários advocatícios (Súmula n 303/STJ). Nesse aspecto, nem sempre terá sido o embargado o causador da constrição indevida, de modo que se mostra factível que o embargante vencedor tenha que arcar com os custos finais dos embargos de terceiro. ${ }^{16}$

13 A legislação espanhola destoa um pouco da brasileira, pois o art. 394 da Ley de Enjuiciamiento Civil assim dispõe: "1. En los procesos declarativos, las costas de la primera instancia se impondrán a la parte que haya visto rechazadas todas sus pretensiones, salvo que el tribunal aprecie, y así lo razone, que el caso presentaba serias dudas de hecho o de derecho. Para apreciar, a efectos de condena en costas, que el caso era jurídicamente dudoso se tendrá en cuenta la jurisprudencia recaída en casos similares".

14 DINAMARCO, Cândido Rangel. Instituições de direito processual civil. 7. ed. Vol. II. São Paulo: Malheiros, 2017, n. 884, p. 760.

15 DINAMARCO, Cândido Rangel. Instituições de direito processual civil, cit., p. 761. Há quem entenda, porém, que a sucumbência constitui o foco primordial do sistema do CPC/2015, sendo a causalidade uma exceção ao princípio da sucumbência (SCARPINELLA BUENO, Cassio. Curso sistematizado de direito processual civil. 9. ed. Vol. I. São Paulo: Saraiva, 2018, p. 491).

16 ARAÚJO, Fabio Caldas de. Curso de processo civil. Tomo I. São Paulo: Malheiros, 2016, p. 516-517. 
De parte o aspecto relativo ao custo do processo, os honorários advocatícios também configuram remuneração do profissional da advocacia. Tanto assim que o art. 23 da Lei n 8.906/94 estabelece que os honorários incluídos na condenação, por arbitramento ou sucumbência, pertencem ao advogado, tendo este direito autônomo para executar a sentença no aspecto relativo aos honorários, podendo requerer que o precatório, quando necessário, seja expedido em seu favor. ${ }^{17}$

De modo explícito, o CPC consagra que os honorários constituem direito do advogado e têm natureza alimentar, ${ }^{18}$ com os mesmos privilégios dos créditos oriundos da legislação do trabalho, sendo vedada a compensação em caso de sucumbência parcial (art. 85, § 14, do CPC). ${ }^{19}$ Bem é de ver que a jurisprudência tem se orientado no sentido de que os honorários advocatícios sucumbenciais gozam de preferência, inclusive, quanto ao crédito do próprio mandante. ${ }^{20}$

O advogado também goza da prerrogativa chamada reserva de honorários: se o advogado fizer juntar aos autos o seu contrato de honorários antes de expedir-se o mandado de levantamento ou precatório, o juiz deve determinar que lhe sejam pagos diretamente, por dedução da quantia a ser recebida pelo constituinte, salvo se este provar que já os pagou (art. 22, § 4º, da Lei nº 8.906/94).

A autonomia e a titularidade do direito aos honorários advocatícios estão refletidas na regra do art. 99, § 50, do CPC, pois o advogado particular de beneficiário da gratuidade da justiça deve recolher o preparo na hipótese de recurso que verse exclusivamente sobre o valor de honorários de sucumbência, salvo se o próprio advogado demonstrar que tem direito à gratuidade.

Na perspectiva do arbitramento dos honorários sucumbenciais, o critério fundamental está previsto no art. $85, \S 2^{\circ}$, do CPC, conforme o qual os honorários serão fixados entre o mínimo de $10 \%$ e o máximo de $20 \%$ sobre o valor da condenação, do proveito econômico obtido ou, não sendo possível mensurá-lo, sobre o valor atualizado da causa. Para definição do percentual no caso concreto, o julgador deve analisar os seguintes critérios: (a) grau de zelo do profissional; (b) lugar da prestação do serviço; (c) natureza e importância da causa; (d) trabalho realizado pelo advogado e tempo exigido para o seu serviço. Interessante observar que esses critérios são aplicáveis seja qual for o conteúdo da decisão (ou sentença), inclusive nas hipóteses de improcedência e de sentença (ou decisão) sem resolução de mérito (art. $85, \S 6^{\circ}$, do CPC).

17 Destaca-se o enunciado 47 da Súmula Vinculante do STF: "Os honorários advocatícios incluídos na condenação ou destacados do montante principal devido ao credor consubstanciam verba de natureza alimentar cuja satisfação ocorrerá com a expedição de precatório ou requisição de pequeno valor, observada ordem especial restrita aos créditos dessa natureza".

18 Exatamente por isso é que se admite a penhora de verbas que, a princípio, seriam absolutamente impenhoráveis, para fins de satisfação, in executivis, de obrigação fundada em honorários advocatícios contratuais ou sucumbenciais (STJ, AgRg no REsp 1.297.419/SP, 3ª T., Rel. Min. Sidnei Beneti, j. 19.04.2012; TJSP, Al 201630620.2017.8.26.0000, 31 a Câmara de Direito Privado, Rel. Des. Paulo Ayrosa, j. 04.04.2017). Porém há significativa jurisprudência em senso contrário: TJSP, Al 2005864-92.2017.8.26.0000, 6ª Câmara de Direito Público, Rel. Des. Sidney Romano dos Reis, j. 03.04.2017, com farta indicação de outros julgados.

19 Diante dessa regra, ficou superado o entendimento cristalizado na Súmula $n^{\circ} 306 / S T J$.

20 TJSP, Al 2216898-46.2018.8.26.0000, 22ª Câmara de Direito Privado, Rel. Des. Edgar Rosa, j. 18.02.2019; TJSP, Al 2074712-68.8.26.0000, 5a Câmara de Direito Privado, Rel. Des. Moreira Viegas, j. 15.06.2016. 
A rigidez dos percentuais e dos critérios acima referidos pode ser afastada nas causas em que for inestimável ou irrisório o proveito econômico ou, ainda, quando o valor da causa for muito baixo, circunstâncias que autorizam o juiz a fixar o valor dos honorários por apreciação equitativa (art. 85, § $8^{\circ}$, do (PC). Há quem entenda que, nas hipóteses de condenações muito elevadas ou de causas com valor muito alto, o juiz possa fixar honorários de modo equitativo, mediante operação que tenha a proporcionalidade como base de sustentação. ${ }^{21}$

Todavia, parece válido afirmar que as regras de fixação dos honorários não podem ser afastadas com base em argumentos que invoquem princípios, pura e simplesmente. ${ }^{22}$ De mais a mais, a expressão inestimável, encontrada no $\S 8^{\circ}$ do art. 85 do CPC, não se presta a justificar o entendimento de que vultosas expressões monetárias sejam inestimáveis, ao menos no contexto do CPC/2015, que estabeleceu regras rígidas de fixação dos honorários.

A graduação dos percentuais nos casos de condenação da Fazenda Pública traduz-se em bom argumento para se chegar à conclusão de que, mediante prévia avaliação do legislador, pretendeuse afastar os subjetivismos na fixação desses valores.

A par dessas regras gerais, o CPC/2015 regula algumas situações específicas, acrescidas aqui a título exemplificativo: (a) se o réu reconhecer a procedência do pedido e, simultaneamente, cumprir integralmente a prestação reconhecida, os honorários serão reduzidos pela metade (art. 90, § $4^{\circ}$ ); e (b) na hipótese de regularização do polo passivo, conforme autorizam os arts. 338 e 339, os honorários do advogado do réu excluído serão fixados entre 3\% e $5 \%$ do valor da causa ou, sendo este irrisório, nos termos do art. $85, \S 8^{\circ}$, tal como estabelece o art. 338, parágrafo único, do CPC.

$\mathrm{Na}$ execução por quantia fundada em título extrajudicial, os honorários são fixados sempre em $10 \%$ do valor do débito em aberto, mas, se o executado pagar a integralidade da dívida no prazo de três dias da citação, são reduzidos pela metade (art. 827, caput e $\S 1^{\circ}$, do CPC). Os honorários iniciais também podem ser majorados até $20 \%$ em duas situações: (a) quando rejeitados os embargos à execução; e (b) no fim da execução, se não opostos os embargos, levando-se em conta o trabalho realizado pelo advogado do exequente (art. $827, \S 2^{\circ}$, do CPC).

No cumprimento de sentença, os honorários advocatícios de $10 \%$ sobre o valor do saldo em aberto são devidos caso não ocorra o pagamento voluntário no prazo de 15 dias, conforme estipula o art. 523, $\S 1^{\circ}$, cuja diretriz se aplica no cumprimento provisório de sentença (art. 520, § $2^{\circ}$, do CPC). ${ }^{23}$

21 Voto vencido da Min. Nancy Andrighi por ocasião do julgamento do REsp 1.746.072/PR, Segunda Seção, j. 13.02.2019, DJe 29.03.2019.

22 Esse foi o entendimento da maioria dos ministros integrantes da Segunda Seção do Superior Tribunal de Justiça no julgamento do REsp 1.746.072/PR, referido na nota anterior. Na doutrina, confira-se SCARPINELLA BUENO, Cassio. Honorários advocatícios e o art. 85 do CPC de 2015: reflexões em homenagem ao professor José Rogério Cruz e Tucci. In: BEDAQUE, José Roberto dos Santos et al. (Coord.). Estudos de direito processual civil em homenagem ao Professor José Rogério Cruz e Tucci. Salvador: JusPodivm, 2018, p. 140-141.

23 É da jurisprudência a orientação segundo a qual a multa do art. $523, \S 1^{\circ}$, do CPC não integra a base de cálculos dos honorários (STJ, REsp 1.757.033/DF, 3ª T., Rel. Min. Ricardo Villas Bôas Cueva, j. 09.10.2018, DJe 15.10.2018). 
A ação monitória também reflete situação especial de fixação de honorários, porquanto o cumprimento da obrigação no prazo fixado no mandado monitório (15 dias) tem a aptidão de reduzir os honorários advocatícios para $5 \%$ do valor atribuído à causa. Apesar do silêncio da lei, deve-se entender aplicável à ação monitória a regra do art. 85, § $8^{\circ}$, nas hipóteses nele indicadas, para que não se promova o aviltamento da atividade da advocacia.

Alterando o paradigma que vinha do CPC/73, o código atual prevê a majoração dos honorários na seara recursal. Para tanto, é indispensável que tenham sido fixados no juízo a quo, autorizando-se a majoração pelo juízo ad quem caso o recurso não alcance resultado exitoso para o recorrente (art. 85, § 11).

Nos termos do Enunciado no 16/Enfam, não é possível majorar os honorários na hipótese de interposição de recurso no mesmo grau de jurisdição, mas há vozes divergentes, como a de Cândido Dinamarco, para quem, "[h]avendo acréscimo nas atividades do advogado, essa majoração será devida mesmo em caso de embargos declaratórios opostos contra decisão de primeiro grau, que serão decididos pelo próprio juízo inferior" ${ }^{24}$

Ainda se discute se a majoração dos honorários pressupõe a apresentação de contrarrazões. Nesse ponto, a tendência jurisprudencial apresenta-se no sentido de que é "dispensada a configuração do trabalho adicional do advogado para a majoração dos honorários na instância recursal, que será considerado, no entanto, para quantificação de tal verba" ${ }^{25}$

Por fim, nas ações em que a Fazenda Pública for parte - e não só naquelas em que for vencida -, os percentuais dos honorários advocatícios seguem regramento próprio e distinto: quanto maior o valor da condenação ou do proveito econômico obtido pela parte, menor será o percentual dos honorários, conforme o escalonamento previsto no art. 85, § $3^{\circ}$, do CPC. Por exemplo, se a condenação superar 100.000 salários mínimos, os honorários serão fixados entre 1\% e 3\% (inciso $\vee$ do $\S 3^{\circ}$ do art. 85 do $(P C)$.

Feita a resenha de aspectos gerais atinentes aos honorários advocatícios, é possível ingressar no enfrentamento do tema proposto. A exposição até aqui lançada serve de premissa, em alguma medida, para o desenvolvimento que vem na sequência.

24 DINAMARCO, C. R. Instituições de direito processual civil, cit., p. 774-775. No STF, há acórdão fixando honorários advocatícios nos embargos de declaração, com a justificativa de que os aclaratórios foram interpostos já sob a vigência do NCPC (STF, ED no AgRg no RE 919.048/RS, 1ª T., Rel. Min. Luiz Fux, j. 31.05.2016, DJe 29.06.2016).

25 STJ, Aglnt nos EREsp 1.539.725/DF, 2 ${ }^{\mathrm{a}}$ Seção, Rel. Min. Antonio Carlos Ferreira, j. 09.08.2017, DJe 19.10.2017. 


\section{HONORÁRIOS ADVOCATÍCIOS: NA TUTELA PROVISÓRIA INCIDENTAL}

A análise que se faz do ponto de vista da natureza da providência jurisdicional almejada permite afirmar que a tutela provisória pode ser cautelar ou antecipada. Essa classificação diz respeito ao tipo de medida judicial empregada para aplacar os efeitos nocivos que o tempo exerce sobre o direito e sobre o processo, tudo a depender das finalidades desejadas. Verificam-se, portanto, diferentes funções exercidas pela tutela provisória: mediante a tutela cautelar, alcançam-se providências conservativas ou meramente assecuratórias, ao passo que a tutela antecipada proporciona a fruição imediata do bem da vida atrelado a determinada situação de vantagem.

Razões vinculadas à noção de urgência exigem, em certos casos, a adoção de medidas que conservem uma situação de fato ou de direito para que, em momento futuro, a atividade jurisdicional tenha condições de ser útil e eficaz. Exemplificativamente, o arresto configura medida cautelar cuja função é preservar um acervo patrimonial, livrando-o do risco de ser dilapidado caso fique à inteira disposição do devedor. Com essa providência, resguarda-se uma situação para que, em momento posterior, a atividade jurisdicional atinja o tônus desejado de eficácia, conferindo ao titular da situação de vantagem exatamente o bem da vida a que tenha direito. Essa é a tutela provisória, fundamentada em urgência, de natureza cautelar.

Noutros casos, todavia, razões imbricadas com a noção de urgência exigem que o próprio bem da vida que se pretende obter mediante atuação jurisdicional seja concedido desde logo, antes de se percorrer todo o arco procedimental destinado à concessão da tutela final ou definitiva. Exemplificase com a seguinte situação: a necessidade de um paciente se submeter a um tratamento médico emergencial pode justificar que o juiz emita ordem que proporcione ao paciente o acesso imediato a esse tratamento. Eis a tutela provisória, fundamentada em urgência, de natureza antecipada (satisfativa).

Nesses dois casos, agora numa perspectiva cronológica, a tutela provisória pode ser requerida incidentalmente, isto é, num momento em que o pedido de tutela definitiva já tenha sido formulado. Toda vez que a tutela provisória, cautelar ou antecipada, for requerida juntamente com o pedido de tutela final ou posteriormente a este, haverá hipótese de tutela provisória incidental. A tutela provisória vem embutida na mesma base procedimental em que veiculado o pedido de tutela final.

Imagine-se que o pedido da parte seja a imposição da obrigação de o INSS implantar determinado benefício previdenciário. Uma vez formulado esse pedido em juízo, toda e qualquer tutela provisória requerida a partir disso será, do ponto de vista cronológico, incidental.

Também a tutela provisória, ainda nessa perspectiva do momento em que requerida, pode ser manifestada antecedentemente. Em outras palavras, a providência caracterizada como tutela provisória pode ser requerida antes da dedução do pedido de tutela final, conforme permite expressamente o 
art. 294, parágrafo único, do CPC. Com essa postura, o CPC/2015 inova e generaliza o cabimento de tutela provisória antecedente tanto para aquelas de natureza cautelar (conservativas) quanto para as de natureza antecipada (satisfativas).Observa-se que, na tutela provisória antecedente - objeto de análise mais à frente -, o procedimento judicial tem início exclusivamente por causa do pedido de tutela provisória, uma vez que nesse momento inicial a parte ainda não formula o pedido tal como categorizado no art. 319, IV, do CPC.

Com base nessa análise prévia sobre as espécies de tutela provisória, apreciadas na perspectiva cronológica, é possível enfrentar a questão dos honorários advocatícios na tutela provisória incidental. Partindo da premissa de que a tutela provisória incidental vem embutida na mesma base procedimental em que se veicula o pedido de tutela final, chega-se à conclusão de que não se verifica aí dualidade de fases procedimentais. A etapa cognitiva do processo será uma só, muito embora no seu âmbito esteja inserido o requerimento de tutela provisória, cautelar ou antecipada.

É verdade que a petição inicial apresentar-se-á mais complexa, porquanto, além de satisfazer todos os requisitos do art. 319 do CPC, conterá um capítulo adicional respeitante à tutela provisória incidental. Caso a tutela provisória não seja requerida já na petição inicial, a parte terá que construir petição avulsa para requerer a providência que almeja.

Em razão do requerimento de tutela provisória incidental, a atividade judicial se incrementa, uma vez que o julgador, além de examinar os requisitos de admissibilidade da demanda, deve apreciar o pleito de tutela provisória, fazendo-o fundamentadamente, de modo claro e preciso (art. 298, do (PC).

Não se pode descartar que, no âmbito das tutelas provisórias fundadas em urgência, a correta aplicação do instituto exija a prestação de caução idônea, real ou fidejussória, nos termos do art. $300, \S 1^{\circ}$, do CPC. Daí que a própria necessidade da caução e sua idoneidade podem gerar discussões capazes de incrementar o contraditório nessa etapa do procedimento.

Semelhantemente, é possível que, para bem decidir o requerimento de tutela provisória, o juiz designe audiência de justificação prévia (art. 300, $\S 2^{\circ}$, do $\mathrm{CPC}$ ), hipótese que demandará maior participação das partes em contraditório. Não bastasse isso, as atividades prévias à audiência de justificação podem acrescer providências a cargo do advogado do requerente, tal como a intimação das testemunhas, ex vi do art. 455 , caput e $\S 1^{\circ}$, do CPC. ${ }^{26}$ Das decisões proferidas em sede de tutela provisória, cabe agravo de instrumento (art. 1.015, inc. I, do CPC), de sorte que a interposição desse recurso eleva a intensidade do contraditório e, por assim dizer, das atividades processuais das partes e de seus advogados.

26 O CPC não regula a audiência de justificação prévia, razão por que se aplicam, no que couber, as regras pertinentes à audiência de instrução e ao julgamento. 
A despeito de todas essas possibilidades, acentua-se que, na perspectiva dos honorários advocatícios, independentemente da concessão ou não de tutela provisória incidental, a sentença (ou alguma decisão parcial de mérito) condenará o vencido a pagar honorários ao advogado do vencedor (art. 85, caput, do CPC).

Disso resulta que, no âmbito específico da tutela provisória, não haverá espaço para fixação autônoma de honorários advocatícios a depender da sorte alcançada pela parte. O fator que comanda a definição do sujeito responsável pelo pagamento dos honorários continua a ser a vitória ou a derrota relativamente ao pedido de tutela final. Assim, mesmo que o autor obtenha alguma tutela provisória incidental, a improcedência do pedido de tutela final ensejará a sua condenação a pagar honorários advocatícios da parte contrária.

Essa ordem de ideias, porém, não afasta a necessidade de o juiz levar em consideração, no exercício do arbitramento dos honorários, as atividades praticadas pelos advogados na etapa em que se discutiu a tutela provisória incidental.

Com efeito, um dos critérios a ser sopesado na fixação entre o mínimo de $10 \%$ e o máximo de $20 \%$ sobre o valor da condenação, o proveito econômico ou sobre o valor da causa consiste no "trabalho realizado pelo advogado" (art. 85, § 20, IV, do CPC).

A exposição que se fez sobre o incremento de atividades provocado pela tutela provisória incidental justifica a tomada de posição no sentido de que referidos acontecimentos hão de integrar a base lógica em que se assentará a fixação dos honorários advocatícios.

Outro critério que deve ingressar na avaliação do arbitramento dos honorários é o "tempo exigido" para a consecução dos serviços do advogado da parte vencedora, nos exatos termos da parte final do inciso IV do $\S 2^{\circ}$ do art. 85 do CPC. Realmente, o incremento de atividades relacionado à tutela provisória incidental, seja ela cautelar ou antecipada, pode exigir mais tempo do profissional da advocacia, circunstância que há de ser valorada pelo julgador.

E o tempo aqui referido não quer significar a simples duração do processo. A rigor, a tutela provisória incidental, porquanto embutida no mesmo arco procedimental do pedido de tutela final, não provoca dilatação do procedimento como um todo, de modo que é válido inferir que a duração do processo não sofrerá ampliações significativas. Contudo não é apenas disso que trata a parte final do inciso IV do $\S 2^{\circ}$ do dispositivo acima referido, pois o tempo exigido para o serviço do advogado condiz com a noção de quanto trabalho adicional foi gerado e de quanto isso significou de investimento de tempo do profissional. ${ }^{27}$

27 Em suma, deve-se levar em conta "o tempo efetivamente gasto com o processo" e "o tempo de duração do próprio processo” (LOPES, Bruno Vasconcelos Carrilho. Honorários advocatícios no processo civil. São Paulo: Saraiva, 2008, n. 37, p. 152). 
Daí a conclusão parcial de que os honorários devidos ao advogado do vencedor serão arbitrados levando-se em conta, entre outros critérios, o trabalho realizado pelo advogado e o tempo exigido para o serviço, atinentes à tutela provisória incidental.

\section{4. (SEGUE): NA TUTELA PROVISÓRIA CAUTELAR ANTECEDENTE}

Nos casos em que exista para o autor uma urgência qualificada, a ponto de não se poder ou não ser conveniente esperar até que se consiga formular o pedido de tutela final, a lei permite que o demandante construa uma petição inicial reduzida, cujo conteúdo dirá respeito tão somente à tutela provisória. Essa é a tutela provisória requerida antecedentemente, que pode ter natureza cautelar, conforme já exposto. Nessa hipótese - diz a lei -, a petição inicial da ação que visa à prestação de tutela cautelar em caráter antecedente indicará a lide e seu fundamento, a exposição sumária do direito que se objetiva assegurar e o perigo de dano ou o risco ao resultado útil do processo (art. 305, do CPC).

Vê-se que o processo tem início com a formulação, mediante petição inicial, do pedido de tutela cautelar, pura e simplesmente. Inaugura-se, por assim dizer, uma fase prévia do processo, destinada a dar vazão exclusivamente ao pleito de medida conservativa. O objeto do processo, nesse momento, diz respeito exclusivamente à prestação de tutela cautelar destinada a assegurar o direito contra os perigos do tempo. Só depois de resolvida essa questão pertinente à concessão de tutela cautelar antecedente é que o autor terá oportunidade para aditar a petição inicial e, aí sim, deduzir o seu pedido principal (art. 308, caput, do CPC).

Ocorre que, entre a formulação da petição inicial (art. 305, do CPC) e a dedução do pedido de tutela final (art. 308), existe um procedimento antecedente que merece ser analisado, pois no seu âmbito verificar-se-á uma gama significativa de atividades processuais.

De fato, estando a petição inicial em termos, o réu será citado para, em cinco dias, contestar o pedido cautelar e indicar as provas que pretende produzir (art. 306). Se não houver contestação, o procedimento fica abreviado, já que os fatos alegados presumir-se-ão aceitos pelo réu como ocorridos (art. 307, caput, do CPC). Todavia, se o réu oferecer contestação e controverter os fatos alegados pelo autor, a lei determina que se observe, a partir daí o procedimento comum (art. 307, parágrafo único, do (PC).

A amplitude do procedimento comum, em especial na sua perspectiva instrutória, já revela que inúmeras atividades processuais poderão surgir na fase em que se processa a tutela cautelar requerida antecedentemente. Com efeito, não se pode descartar que, dentre as provas relevantes para a decisão, avulte indispensável a produção de prova testemunhal e pericial, que se colocam, geralmente, como as mais trabalhosas do processo. 
Seja como for, essa etapa cautelar antecedente finda-se com a decisão que resolve o seu mérito, concedendo ou não a medida assecuratória pretendida pelo autor, após o que se abre oportunidade para aditamento da inicial e formulação do pedido principal, quando, então, o mesmo processo transmuda-se naquele destinado a dar vazão ao pedido de tutela final. Numa figura de linguagem, a fase provisória se metamorfoseia em fase definitiva, mediante o aditamento da petição inicial previsto no art. 308, caput, do CPC.

Não se pode perder de vista que, contra a decisão interlocutória, que concede ou não a tutela cautelar requerida antecedentemente e ainda contra aquela que condiciona a sua concessão a alguma medida de contracautela, cabe recurso de agravo de instrumento (art. 1.015, I, do CPC). De qualquer forma, a efetiva dedução do pedido de tutela final, mediante aditamento da petição inicial, põe fim ao segmento cautelar e inaugura a fase definitiva do processo, sem solução de continuidade do procedimento.

Se não há encerramento da fase cognitiva do processo, chega-se à conclusão de que não existe espaço para fixação autônoma de honorários advocatícios para a fase exclusivamente cautelar.

Porém a atividade processual realizada na fase cautelar antecedente, que constitui inegavelmente um alargamento do arco procedimental, há de ser levada em conta por ocasião da sentença, a fim de que o juiz condene o vencido a pagar honorários advocatícios e valore, entre outros critérios, o trabalho realizado pelo advogado e o tempo exigido para o seu serviço.

Em suma, a situação até agora retratada não se distingue daquela exposta a respeito dos honorários na tutela provisória incidental (n. 3, supra), uma vez que, em ambas as hipóteses, não haverá fixação autônoma de honorários advocatícios, mas o incremento de atividade processual servirá como mais um fator para arbitramento da verba honorária.

Noutra ordem de ideias, não se pode perder de vista que o processo que se inicia com o pedido de tutela cautelar antecedente pode ser extinto prematuramente, sem que se avance para a fase da tutela definitiva. Partindo sempre da premissa de que o réu tenha apresentado a contestação a que alude o art. 306, do CPC, podem ocorrer, grosso modo, três situações: (a) extinção por falta de algum requisito de admissibilidade da demanda (art. 485, do CPC); (b) extinção por ausência do aditamento da petição inicial no prazo legal (art. 309, I, do CPC):28 (c) reconhecimento de decadência ou prescrição (art. 310, in fine, c.c. o art. 487, II, ambos do CPC).

Note-se que, nos três casos acima indicados, o processo, inaugurado sob a perspectiva cautelar antecedente, não prosseguirá de modo algum, razão pela qual haverá ambiente para se falar em sentença terminativa, nas hipóteses (a) e (b), e em sentença definitiva, na hipótese (c).

28 No sentido de que a não formulação do pedido principal gera a extinção do processo, confira-se: STJ, AgInt no AREsp 535.138/PB, 4ª T., Rel. Min. Marco Buzzi, j. 15.05.2018, DJe 28.05.2018; STJ, Aglnt no REsp 1.755.331/ MG, $3^{\mathrm{a}}$ T., Rel. Marco Aurélio Bellizze, j. 12.11.2018, DJe 16.11.2018. 
Dentro dessa configuração, o juiz proferirá sentença que condenará o vencido a pagar honorários do advogado do vencedor (art. 85, caput), lembrando-se de que a premissa fundamental para essa conclusão está no fato de o réu ter oferecido a contestação prevista no art. 306, do CPC. É que, se o réu for revel, a extinção do processo nos casos já referidos não renderá ensejo à fixação de honorários a serem pagos pelo autor.

Os critérios para fixação desses honorários são aqueles genericamente previstos nos $\S \S 2^{\circ}$ a $4^{\circ}$ do art. 85 do CPC, conforme o caso. E, se houver recurso contra a sentença de extinção, os honorários podem ser majorados na fase recursal (art. 85, § 11, do CPC).

\section{5. (SEGUE): NA TUTELA PROVISÓRIA ANTECIPADA ANTECEDENTE}

Tal como explanado no item anterior, razões atreladas à noção de urgência qualificada podem exigir da parte a formulação de pedido que se limita a ter por objeto a tutela antecipada (satisfativa). A necessidade de fruição imediata do bem da vida é tão premente que aguardar a construção integral da petição que obedeça aos requisitos dos arts. 319 e 320, ambos do CPC, pode ensejar o perecimento daquele mesmo bem da vida. "A admissão dessa técnica de tutela pressupõe uma situação de urgência incompatível com a demora inerente à elaboração da petição inicial da ação". ${ }^{29}$

Para tais casos, prevê-se que a petição inicial pode limitar-se ao requerimento da tutela antecipada e à indicação do pedido de tutela final, com a exposição da lide, do direito que se busca realizar e do perigo de dano ou do risco ao resultado útil do processo (art. 303, caput, do CPC). Esse tipo de construção mais reduzido da petição inicial só se admite porque o autor haverá de indicar que oportunamente aditará a petição inicial (art. 303, § 1º l, do CPC). Ou seja, o autor tem de explicitar na petição inicial que está agindo em situação de excepcional urgência e que, por isso mesmo, vale-se da referida prerrogativa (art. $303, \S 5^{\circ}$, do CPC).

Fácil perceber que, nesse esquema, o procedimento desdobrar-se-á em duas fases: a primeira destinada a veicular apenas a tutela provisória antecipada, e a segunda vocacionada a dar trânsito à tutela definitiva (pedido de tutela final), que se inicia com o aditamento a que alude o inciso I do $\S 1^{\circ}$ do art. 303 do CPC. Essa noção de fases ou de etapas é importante para mostrar que tudo se dá num mesmo processo, embora a fase antecedente provoque um inevitável alargamento do procedimento como um todo.

Conquanto a tutela antecipada requerida antecedentemente seja passível de estabilização (art. 304, caput, do (PC), neste tópico da exposição, quer-se trabalhar exclusivamente com a hipótese em que não ocorra a estabilização, seja por opção do próprio autor, seja por efeito da interposição de recurso pelo réu (art. 304, caput, in fine, do CPC).

29 MARINONI, Luiz Guilherme. Tutela de urgência e tutela da evidência. ed. São Paulo: RT, 2017, p. 228. 
Em síntese, aqui se analisa a situação em que o autor formula pedido de tutela antecipada antecedente e depois adita a petição inicial para dedução do pedido de tutela final, de modo que a fase antecedente do processo seja sucedida pela fase definitiva desse mesmíssimo processo.

O que interessa notar é que a fase procedimental da tutela provisória antecipada antecedente provoca atividades processuais que só se justificam nesse âmbito.

Com efeito, o autor tem o ônus de construir a petição inicial descrita no art. 303, do CPC, e é possível que o juiz exija caução idônea como condição para deferimento da tutela provisória requerida (art. 300, $\S 1^{\circ}$, do CPC). Isso já mostra o incremento do contraditório e a multiplicação de atividades processuais a cargo da parte. E não se pode perder de vista a possibilidade de designação de audiência de justificação (art. 300, § $2^{\circ}$, do CPC) com todas as suas nuances.

Seja como for, da concessão ou não de tutela antecipada antecedente, cabe recurso de agravo de instrumento (art. 1.015, inc. I, do CPC), circunstância que eleva, quantitativa e qualitativamente, o nível das atividades processuais.

Toda essa atividade processual está circunscrita à fase antecedente, necessariamente sucedida pela fase definitiva do processo. Em razão dessa circunstância e à semelhança do que se defendeu anteriormente (n. 4, supra), não serão arbitrados honorários advocatícios autônomos para essa específica fase.

Justifica-se essa posição na consideração de que o aditamento da petição inicial, tal como regulado pelo art. 303, $\S 1^{\circ}, 1$, do CPC, provoca a continuidade do processo, o qual seguirá os trâmites naturais do procedimento comum. Somente no fim da fase cognitiva do procedimento comum é que se estabelecerá a parte sucumbente, quando então a sentença condenará o vencido a pagar honorários do advogado do vencedor (art. 85, caput, do CPC). É nesse momento que o julgador adotará o "trabalho realizado" e o "tempo exigido" na construção da etapa antecedente da tutela provisória como mais um elemento balizador da fixação dos honorários advocatícios de sucumbência.

Em outra perspectiva, não se pode desconsiderar que o processo iniciado com o pedido de tutela antecipada antecedente venha a ser extinto prematuramente, sem que se avance para a fase da tutela definitiva.

Estabelecida a hipótese de que o réu tenha interposto recurso contra a decisão que defira a tutela antecipada antecedente ou manifestado algum tipo de resistência ao pedido de tutela provisória, podem ocorrer, grosso modo, três situações: (a) extinção do processo por falta de algum requisito de admissibilidade da demanda (art. 485, do CPC); (b) extinção por ausência do aditamento da petição inicial no prazo legal (art. 303, § $2^{\circ}$, do CPC); (c) reconhecimento de decadência ou prescrição (art. 310, in fine, c.c. o art. 487, II, ambos do CPC, aplicados aqui por analogia). 
Bem é de ver que, nos três casos acima indicados, o processo, inaugurado sob a perspectiva antecedente, não prosseguirá de modo algum, razão pela qual haverá ambiente para se falar em sentença terminativa, nas hipóteses (a) e (b), e em sentença definitiva, na hipótese (c).

Nessa configuração, o juiz proferirá sentença e condenará o vencido a pagar honorários do advogado do vencedor (art. 85, caput, do CPC). ${ }^{30}$ A premissa fundamental para essa conclusão está no fato de o réu ter oferecido algum tipo de resistência ao pedido de tutela provisória, gerando-se, com isso, alguma atividade do profissional da advocacia. Diferentemente, se o réu for revel, a extinção do processo nos casos já referidos não ensejará a fixação de honorários a serem pagos pelo autor.

Os critérios para fixação desses honorários são aqueles genericamente previstos nos $\S \S 2^{\circ}$ a $4^{\circ}$ do art. 85 do CPC, conforme o caso. E se houver recurso contra a sentença de extinção, os honorários podem ser majorados na fase recursal (art. 85, § 11, do CPC).

\section{6. (SEGUE): NA TUTELA PROVISÓRIA ESTABILIZADA}

A estabilização da tutela provisória talvez seja um dos assuntos mais instigantes da nova codificação e, como não poderia ser diferente, é capaz de suscitar dúvidas também na seara dos honorários advocatícios. Nos termos da lei, a tutela antecipada concedida em momento antecedente torna-se estável se, da decisão que a conceder, não for interposto o respectivo recurso (art. 304, caput, do (PC). ${ }^{31} \mathrm{O}$ interessante é que, uma vez estabilizada a tutela antecipada, extingue-se o processo (art. 304, § $1^{\circ}$, do CPC). Nesses moldes, "reconhece-se que a tutela que disciplinou provisoriamente a relação de direito material está apta a satisfazer os interesses práticos das partes envolvidas, diminuindo ou eliminando a necessidade de discussão do mérito". ${ }^{32}$

Um exemplo pode auxiliar na compreensão: o autor pede a determinação judicial de que a operadora de plano de saúde Ihe forneça determinado tratamento médico, isso no âmbito da tutela provisória de natureza antecipada e requerida antecedentemente. Concedida a ordem judicial (rectius, deferida a liminar), o réu não interpõe o recurso cabível contra referida decisão. Diante disso, estabiliza-se a tutela provisória, mediante a perenização dos efeitos práticos da decisão.

30 Tenha-se presente que a extinção do processo, nas situações (a) e (c), pode ser determinada em sede recursal, mediante o provimento, por exemplo, de agravo de instrumento interposto pelo réu. $\mathrm{O}$ acórdão, então, fixará as verbas de sucumbência de maneira originária, conforme os mesmos critérios indicados no texto.

31 "Em sentido técnico, recurso é o pedido de reexame, reforma ou esclarecimento de uma decisão ou sentença. Regem a matéria os princípios da legalidade e da taxatividade de modo que só se deveriam admitir, na hipótese, os recursos previstos na lei processual. Contudo, considerando-se as graves consequências que decorrem da estabilização, impõe-se interpretação extensiva para se admitir qualquer forma de impugnação manifestada pelo réu" (LOPES, João Batista. Tutela antecipada no processo civil brasileiro. 5. ed. São Paulo: Editora Castro Lopes, 2016, p. 180-181). Posição diversa é sustentada por Bedaque, para quem somente o recurso, entendido em sentido técnico-processual, constitui meio hábil a evitar a estabilização (BEDAQUE, José Roberto dos Santos. Comentário ao art. 304 do CPC. In: SCARPINELLA BUENO, Cassio. (Coord.). Comentários ao Código de Processo Civil. Vol. 1. São Paulo: Saraiva, 2017, p. 944).

32 ALVIM, Eduardo Arruda. Tutela provisória. 2. ed. São Paulo: Saraiva, 2017, p. 200. 
Apesar de não equivaler à coisa julgada (art. 304, § 6º, do CPC), a tutela provisória estabilizada conservará seus efeitos enquanto não revista, reformada ou invalidada por decisão de mérito proferida na ação de que trata o $\S 2^{\circ}$ do art. 304 do CPC. Veja-se que não é o conteúdo da decisão que se torna estável, mas os efeitos práticos dela decorrentes que perduram no tempo. ${ }^{33}$

Para afastar a estabilidade já operada, o CPC estabelece que qualquer das partes poderá, no prazo de dois anos contados da ciência da extinção do processo, demandar a outra com o intuito de rever, reformar ou invalidar a tutela antecipada estabilizada (art. $304, \S \S 2^{\circ}$ e $5^{\circ}$, do CPC).

Coerentemente com a premissa segundo a qual a disciplina provisória da relação de direito material satisfaz os interesses práticos das partes naquele processo, o CPC estabelece que, uma vez estabilizada a tutela antecipada, o processo no bojo da qual é concedida deve ser extinto (art. 304, § $1^{\circ}$, do (PC). Profere-se, assim, sentença terminativa, ${ }^{34}$ que não resolve o mérito da causa e, por isso mesmo, não é apta à formação de coisa julgada material. ${ }^{35}$

Seja como for, trata-se de sentença que, depois de esgotadas as vias impugnativas, transita em julgado e põe fim ao processo. Logo a sentença deve sujeitar o vencido a pagar honorários ao advogado do vencedor (art. 85, caput, do CPC), ainda que se cuide de sentença sem resolução do mérito (art. 85, § 6, in fine, do CPC). De fato, "não há qualquer ressalva no novo CPC no sentido de que essa particular hipótese de sentença terminativa não conteria a fixação da responsabilidade pelas verbas de sucumbência". ${ }^{36}$

Importa observar que, na situação ora versada, não haverá propriamente vencedor e vencido, já que a estabilização decorre simplesmente da falta de interposição de recurso contra a decisão interlocutória que deferiu a tutela provisória requerida antecedentemente. Não se verifica, a rigor, derrota do réu que não interpõe o recurso, e a sentença proferida nessa hipótese tem natureza terminativa, pois a atividade jurisdicional esgota-se com a estabilização, dando margem segura a falar-se, segundo a linguagem do CPC, em perda do objeto daquele específico processo.

Conquanto a extinção sem resolução do mérito traga consigo indício forte de que o processo seja inadmissível ou de que não esteja apto a prosseguir por algum comportamento imputável ao autor (art. 485, I a IX, do CPC), o certo é que, na estabilização da tutela antecipada antecedente, a realidade é diversa.

33 MARINONI, Luiz Guilherme. Tutela de urgência e tutela da evidência, cit., p. 238.

34 SICA, Heitor Vitor Mendonça. Doze problemas e onze soluções quanto à chamada "estabilização da tutela antecipada". In: SCARPINELLA BUENO, Cassio. (Coord.). Tutela provisória no novo CPC. São Paulo: Saraiva, 2016, p. 412.

35 LOPES, Bruno Vasconcelos Carrilho. Estabilização da tutela antecipada e coisa julgada. In: SCARPINELLA BUENO, Cassio. (Coord.). Tutela provisória no novo CPC, op. cit., p. 203.

36 SICA, Heitor Vitor Mendonça. Doze problemas e onze soluções quanto à chamada "estabilização da tutela antecipada", cit., p. 416. 
Com efeito, a necessidade de o autor ir a juízo pleitear a tutela antecipada antecedente decorre de algum comportamento do réu, omissivo ou comissivo, que não satisfez, total ou parcialmente, a pretensão do autor na esfera extrajudicial. Pode-se entrever que o interesse de agir do autor extrai-se de algum obstáculo criado (ou não retirado) pelo réu a ponto de gerar perigo à provável situação de vantagem que ampara o demandante.

Noutros termos, o perigo de dano imposto ao direito afirmado pelo autor advém de alguma postura adotada pelo réu, o qual, assim agindo, terá dado causa à demanda em que se postula apenas a tutela provisória antecedente. Daí que, estabilizada a tutela provisória, aquele risco tende a se extirpar, haja vista a natureza satisfativa da tutela provisoriamente concedida. Bem por isso é que, esgotada a atividade judicial nesse prisma, o processo se extingue sem resolução do mérito.

Tal cenário revela que o réu terá dado causa ao ajuizamento do pedido de tutela provisória antecedente, motivo por que se sujeita a pagar os honorários do advogado do autor, ${ }^{37} \mathrm{com}$ fundamento no que dispõe o art. $85, \S 10$, do CPC.

Note-se que esses honorários são fixados na sentença de extinção do processo, e não na própria decisão que defere a tutela antecipada antecedente. Para fins de arbitramento dos honorários, as regras aplicáveis são aquelas genericamente explicitadas no art. 85 , $\S \S 2^{\circ}$ e $3^{\circ}$, do CPC, sem nenhum outro temperamento, conforme determina o $\S 6^{\circ}$ do mesmo dispositivo.

Relevante mencionar, nesse passo, que a ausência de impugnação do réu quanto à decisão que defere a tutela antecipada não é capaz de lhe render benefício ou prêmio no que toca aos honorários advocatícios. Isso deve ser dito porque já se cogitou de aplicar, na hipótese, regra semelhante àquela que regula o assunto no âmbito da ação monitória, com redução da verba honorária caso o réu cumpra o mandado monitório no prazo legal de 15 dias (art. 701, caput, do CPC).

Conquanto não se neguem as semelhanças entre a técnica da estabilização e a da ação monitória, ${ }^{38}$ parece mais adequado entender que, nesse particular aspecto, as diferenças avultam e, por isso, ensejam tratamentos díspares. Com efeito, a estabilização da tutela antecipada, por si só, "não implica satisfação do autor, mas apenas a formação de título para a execução definitiva", 39 ao passo que o cumprimento voluntário do mandado monitório satisfaz inteiramente o direito reclamado pelo autor a justificar a redução dos honorários na monitória, circunstância que, evidentemente, não se verifica na estabilização da tutela antecipada.

37 SICA, Heitor Vitor Mendonça. Doze problemas e onze soluções quanto à chamada "estabilização da tutela antecipada", cit., p. 416.

38 TALAMINI, Eduardo. Tutela de urgência no projeto de novo Código de Processo Civil: a estabilização da medida urgente e a "monitorização" do processo civil brasileiro. Revista de processo, São Paulo, ano 37, v. 209, n. 8, p. 24-25, jul./2012.

39 SICA, Heitor Vitor Mendonça. Doze problemas e onze soluções quanto à chamada "estabilização da tutela antecipada", cit., p. 416. 
Questão elegantíssima refere-se ao destino dos honorários advocatícios fixados nos moldes aqui defendidos quando se julga procedente a ação destinada a rever, cassar ou reformar a tutela antecipada estabilizada. Questiona-se: qual será a sorte dos honorários advocatícios, devidos na tutela provisória estabilizada, se acolhida a ação a que alude o art. 304, § $2^{\circ}$, do CPC? Tal assunto não constitui grande novidade, pois fenômeno similar eclode no âmbito da ação rescisória julgada procedente. Isso não significa, porém, que o tema já esteja equacionado, haja vista que são visualizadas pelo menos duas orientações divergentes no mesmo Tribunal Superior.

Realmente, o STJ já proclamou que o acolhimento da ação rescisória enseja a restituição dos honorários de sucumbência recebidos, pois deixa de existir a decisão que lhes deu causa. ${ }^{40}$ Assim se tem considerado, porque

[...] o capítulo da sentença referente aos honorários está indiscutivelmente atrelado ao resultado da lide consagrado no respectivo título judicial, de modo que a desconstituição da coisa julgada atingirá não apenas a relação jurídica travada entre vencedor e vencido da demanda original, mas também aquela estabelecida entre o advogado e a parte anteriormente vencida, agora vencedora da ação rescisória. ${ }^{41}$

Diversamente, já se entendeu que a procedência da rescisória no que toca à relação jurídica travada entre as partes do processo originário não implica automático desfazimento do capítulo pertinente aos honorários sucumbenciais fixados na origem, "haja vista a total independência entre cada um dos vínculos jurídicos que se forma com o trânsito em julgado da decisão rescindenda". Assim, a autonomia que se empresta aos honorários sucumbenciais, a ausência de acessoriedade quanto à relação jurídica dos constituintes (clientes), o caráter alimentar da verba e a percepção dos valores com boa-fé afastam a possibilidade de se impor a repetição só por conta da procedência da ação rescisória. ${ }^{42}$

A doutrina tende a negar, como regra geral, que os honorários de sucumbência devem ser restituídos como decorrência automática do julgamento de procedência da ação rescisória, com a ressalva de que a repetição pode verificar-se quando os honorários são recebidos de má-fé. ${ }^{43}$

40 STJ, REsp 1.549.836/RS, $3^{a}$ T., Rel. Min. João Otávio de Noronha, j. 17.05.2016, DJe 06.09.2016. No mesmo sentido parece ser a posição da Min. Nancy Andrighi, conforme registrado no voto proferido na Ação Rescisória 5.160/RJ, $2^{\mathrm{a}}$ Seção, j. 28.02.2018, DJe 18.04.2018.

41 STJ, AgRg na Ação Rescisória 3.290/SP, 2a Seção, Rel. Min. Castro Meira, j. 25.05.2011, DJe 02.06.2011. Em razão dessa construção, o advogado é parte legítima para figurar no polo passivo da ação rescisória em que se pede a desconstituição do capítulo pertinente aos honorários de sucumbência (STJ, REsp 1.651.057/CE, $3^{\mathrm{a}} \mathrm{T}$., Rel. Min. Moura Ribeiro, j. 16.05.2017, DJe 26.05.2017).

42 Argumentos extraídos do voto-vista do Min. Antonio Carlos Ferreira, proferido na Ação Rescisória 5.160/RJ, $2^{\mathrm{a}}$ Seção, j. 28.02.2018, DJe 18.04.2018. Nos termos desse voto, o desfazimento da condenação aos honorários de sucumbência pressupõe pedido expresso para desconstituição desse capítulo do julgado, "necessariamente amparado em fundamento que autorize rescindir tão somente a condenação da verba sucumbencial. Para tanto, o autor da rescisória deve indicar o enquadramento legal de sua pretensão, apenas em relação aos honorários advocatícios, no rol exaustivo previsto na lei processual de regência".

43 APRIGLIANO, Ricardo de Carvalho. Ações rescisórias que versem sobre honorários de sucumbência: considerações sobre admissibilidade e mérito. In: BEDAQUE, José Roberto dos Santos et al. (Coords.). Estudos de direito processual civil em homenagem ao Professor José Rogério Cruz e Tucci. Salvador: JusPodivm, 2018, p. 690-691. 
Conquanto esse tema ainda seja merecedor de aprofundada reflexão, incabível no ambiente restrito deste trabalho, é possível ensaiar uma conclusão que parte da premissa de que os honorários sucumbenciais decorrem, primordialmente, da causalidade, isto é, o ponto fulcral de constituição do direito aos honorários advocatícios está relacionado ao fato de a parte ter dado causa, indevidamente, ao processo, circunstância que faz surgir para o advogado do adversário o direito aos respectivos honorários sucumbenciais.

Não se duvida de que a efetiva prestação de serviços advocatícios integre o ciclo de formação daquele direito, mas o elemento primordial é mesmo a causalidade, pois sem esta, a prestação daqueles serviços não se remunera.

Assim, a estabilização da tutela antecipada traz embutida a noção de que o réu deu causa ao processo, e essa causalidade decorre da necessidade criada ou não excluída pelo réu que, adotando determinada postura, levou o autor a precisar da tutela antecipada antecedente. A concessão desse tipo de tutela provisória, somada à ausência de impugnação pelo réu, cristaliza o reconhecimento da causalidade, que desemboca na fixação dos honorários de sucumbência.

Nesse contexto, parece válido afirmar que a exclusão posterior do elemento caracterizador da causalidade na tutela provisória estabilizada, mediante a procedência da ação a que alude o art. 304, $\S 2^{\circ}$, do CPC, faz que a causa de sustentação do direito aos honorários advocatícios seja excluída do cenário jurídico, exigindo-se a restituição dessa verba.

Com efeito, o art. 885 do Código Civil estabelece que a restituição, nos casos de enriquecimento sem causa, é devida não só quando não tenha havido causa que justifique o enriquecimento, mas também se esta deixou de existir. Conforme sinaliza a doutrina, a obrigação de restituir operase "independentemente de a ausência de justa causa ser simultânea ou superveniente à efetiva percepção da atribuição à custa de patrimônio alheio". ${ }^{44}$

Excluída a causalidade mediante a afirmação posterior de que a liminar que justificara a estabilização não tenha tem sustentação, desaparece a causa dos honorários advocatícios sucumbenciais, o que, por si só, justifica a incidência da regra do art. 885 do Código Civil.

A prestação dos serviços advocatícios, isoladamente, não é capaz de justificar a manutenção do direito aos honorários. A percepção da verba honorária com boa-fé não serve de embaraço à aplicação da regra do art. 885 do Código Civil, mais uma vez, porque os honorários derivam primordialmente da causalidade, e não da presença de boa-fé ou de má-fé na atuação do causídico.

Para desencadear a efetiva restituição, o advogado, na condição de titular dos honorários advocatícios, deve figurar no polo passivo da ação em que se busca o reconhecimento do direito

44 SILVA, Rodrigo da Guia. Enriquecimento sem causa: as obrigações restituitórias no direito civil. São Paulo: RT, 2018, p. 196. 


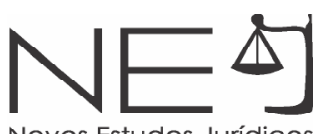

à repetição. Isso se dará na própria ação referida no art. 304, § $2^{\circ}$, do $C P C^{45}$ ou em ação autônoma destinada ao reconhecimento do direito restituitório.

\section{7. (SEGUE): NA EFETIVAÇÃO/EXECUÇÃO DA TUTELA PROVISÓRIA}

Sabe-se que o simples deferimento da tutela provisória, em suas variadas modalidades, não provoca a imediata e automática alteração no mundo exterior, visto que é bem factível o não cumprimento da ordem judicial pelo respectivo destinatário. Para tal situação, o legislador prevê que a efetivação da tutela provisória observará as normas referentes ao cumprimento provisório da sentença, no que couber (art. 297, parágrafo único, do CPC). Em reforço, o art. 519 esclarece que se aplicam as disposições relativas ao cumprimento da sentença, provisório ou definitivo, e à liquidação, no que couber, às decisões que concederem tutela provisória.

A rigor, então, a efetivação da tutela provisória é buscada "não apenas em conformidade com as normas relativas ao cumprimento provisório da sentença, mas também ao definitivo, no que couber". ${ }^{46} \mathrm{E}$ assim deve ser porque "as providências podem variar em função do tipo de medida adequada à situação concreta". ${ }^{47}$

Para os casos de tutela cautelar, a efetivação dar-se-á, exemplificativamente, mediante arresto, sequestro, arrolamento de bens, registro de protesto contra alienação de bem e qualquer outra medida idônea para asseguração do direito (art. 301, do CPC).

A despeito dessa regra e mesmo diante do silêncio do CPC quanto ao modo de efetivação da tutela antecipada, o certo é que "o direito objeto de tutela antecipada deve ser realizado através de meios executivos adequados à sua natureza e à situação de urgência em que se encontra inserido", 48 afirmação que se sustenta diante da proclamação contida no caput do art. 297 do CPC. ${ }^{49}$

Portanto, ainda a título exemplificativo, o julgador pode impor multa, determinar a busca e apreensão, a imissão na posse, a remoção de pessoas ou coisas, o desfazimento de obras e ainda impedir atividades nocivas, tudo sem prejuízo da requisição de força policial e até mesmo da nomeação de terceiro para realizar ou fiscalizar o que deva ser feito..$^{50}$

45 Nessa hipótese, ocorrerá formação de litisconsórcio sucessivo entre a parte em favor de quem se estabilizou a tutela antecipada e seu respectivo advogado. É que haverá nexo de prejudicialidade entre as posições jurídicas da parte e de seu advogado, a justificar essa peculiar figura litisconsorcial (SANTOS, Silas Silva. Litisconsórcio eventual, alternativo e sucessivo. São Paulo: Atlas, 2013, n. 41, p. 202-206).

46 BEDAQUE, José Roberto dos Santos. Comentário ao art. 297, do CPC. In: SCARPINELLA BUENO, Cassio. (Coord.). Comentários ao Código de Processo Civil. Vol. 1. São Paulo: Saraiva, 2017, p. 925.

47 BEDAQUE, José Roberto dos Santos. Comentário ao art. 297, do CPC, cit., p. 924.

48 MARINONI, Luiz Guilherme. Tutela de urgência e tutela da evidência, cit., p. 168.

49 O juiz poderá determinar as medidas que considerar adequadas para efetivação da tutela provisória.

50 MARINONI, Luiz Guilherme. Tutela de urgência e tutela da evidência, cit., p. 168-169. 
Portanto, para superar o descumprimento da ordem contida na decisão que defere a tutela provisória, seja ela cautelar ou antecipada, seja incidental ou antecedente, o sistema processual garante o acesso a atividades executivas tendentes à transformação da realidade sensível, mediante a técnica do cumprimento provisório da sentença, que se processará nos próprios autos ou em autos apartado, evitando-se, nesse caso, tumultos procedimentais.

No que interessa para o presente estudo, observe-se que o art. 520, $\S 2^{\circ}$, inserido no capítulo do CPC atinente ao cumprimento provisório da sentença que condena a pagar quantia, estabelece que os honorários advocatícios a que se refere o art. 523, § $1^{\circ}$, são devidos no cumprimento provisório.

Assim, é de se indagar sobre a incidência de honorários advocatícios autônomos quando instaurado incidente destinado à efetivação da tutela provisória que impuser o pagamento de quantia. E mais, seria possível cogitar a incidência desses honorários advocatícios fora das hipóteses das obrigações de pagar quantia?

A premissa que se afigura válida nesse âmbito está na dicção do art. 85, § 10 , do CPC, consoante a qual são devidos honorários advocatícios no cumprimento de sentença, provisório ou definitivo. Daí que o disposto no art. 520, § $2^{\circ}$, do CPC, nada mais é do que uma singela repetição, para um caso especial de cumprimento provisório, daquilo que já se havia estabelecido na regra geral do art. $85, \S 1^{\circ}$, do CPC. Por conseguinte, em todas as formas de cumprimento provisório de sentença, não importando a natureza da obrigação que se queira fazer cumprir (pagar quantia, fazer, não fazer, entregar coisa), são devidos honorários advocatícios de forma autônoma diante do inegável incremento de atividades processuais causado pela recalcitrância do destinatário da ordem contida no deferimento da tutela provisória.

Nessa conformidade, parece lícito afirmar que a tutela provisória, incidental ou antecedente, que necessitar de um conjunto de atividades ulteriores voltadas à sua efetivação pelo prisma do cumprimento provisório de sentença ensejará a fixação autônoma de honorários advocatícios. Essa mesma conclusão é válida tanto para a tutela provisória cautelar quanto para a antecipada, incluindo-se nesta a chamada tutela da evidência (art. 311, do CPC). Noutra perspectiva, tenhase presente que, nas obrigações de pagar quantia, pode ser necessária a prévia liquidação como mecanismo indispensável para atuação prática da tutela provisória. Tanto assim que o art. 519 do CPC fez referência expressa à liquidação, donde se indagar sobre incidência de honorários advocatícios autônomos no ambiente específico da liquidação.

E a resposta aqui também parece ser afirmativa, desde que a liquidação ganhe contornos de litigiosidade. De fato, o STJ já sedimentou que é entendimento da Corte "a possibilidade de fixação de honorários advocatícios na fase de liquidação de sentença, desde que tenha assumido nítido caráter contencioso"..$^{51}$

51 STJ, AgRg no REsp 1.527.328/SP, 3ª T., Rel. Min. Moura Ribeiro, j. 24.05.2016, DJe 06.06.2016. 
Tendo em vista a semelhança que existe entre a hipótese aqui versada (efetivação de tutela provisória) e aquela que decorre de sentença impugnada por recurso não dotado de efeito suspensivo, ${ }^{52}$ soa adequada a aplicação do mesmo regime para ambas as situações. É dizer: se incidem honorários advocatícios na liquidação de sentença impugnada por recurso não dotado de efeito suspensivo, não há motivos para se afastar a incidência de honorários na liquidação de tutela provisória, desde que o incidente tenha assumido caráter contencioso.

\section{CONSIDERAÇÕES FINAIS}

A tutela provisória causa impactos na seara dos honorários advocatícios. Na maioria das vezes, não existirá a condenação autônoma em verba honorária só por causa da tutela provisória. É o que acontece sempre na tutela provisória incidental. No âmbito da cautelar antecedente, havendo prosseguimento do processo rumo à definição da tutela final, não haverá condenação autônoma atinente aos honorários advocatícios. Esse mesmo cenário se verifica na tutela antecipada antecedente que não se estabiliza.

Porém, em todos esses casos, o acréscimo de trabalho e de tempo exigido para a tratativa processual da tutela provisória servirá de critério para o juiz, no fim do processo, fixar o montante dos honorários de sucumbência a cargo da parte vencida.

De outra parte, existem os casos em que se admite possível a condenação autônoma a pagar honorários de sucumbência no ambiente exclusivo da tutela provisória. Desde que haja atividade processual defensiva pelo réu, por meio de seu respectivo advogado, são cabíveis honorários sucumbenciais autônomos, a serem pagos pelo autor, nas seguintes hipóteses: (a) tutela cautelar antecedente extinta (a1) em razão da falta de preenchimento de algum requisito de admissibilidade (ilegitimidade, por exemplo), (a2) em razão da falta do aditamento referido no art. 308, caput, do CPC e (a3) em razão do reconhecimento de prescrição ou decadência; (b) tutela antecipada antecedente extinta (b1) em razão da falta de preenchimento de algum requisito de admissibilidade (ilegitimidade, por exemplo), (b2) em razão da falta do aditamento referido no art. 303, § $2^{\circ}$, do CPC e (b3) em razão do reconhecimento de prescrição ou decadência.

Ainda são devidos honorários advocatícios sucumbenciais, de forma autônoma, na hipótese de estabilização da tutela provisória, quando então serão devidos pelo réu.

Por fim, em sede de efetivação ou execução de tutela provisória, a depender da efetiva necessidade de instauração de um módulo procedimental executivo, serão devidos honorários advocatícios autônomos, inclusive, no ambiente da liquidação se for verificada alguma litigiosidade.

52 BEDAQUE, José Roberto dos Santos. Comentário ao art. 297, do CPC. In: SCARPINELLA BUENO, Cassio. (Coord.). Comentários ao Código de Processo Civil. Vol. 1. São Paulo: Saraiva, 2017, p. 925. 


\section{REFERÊNCIAS DAS FONTES CITADAS}

ALVIM, Eduardo Arruda. Tutela provisória. 2. ed. São Paulo: Saraiva, 2017.

APRIGLIANO, Ricardo de Carvalho. Ações rescisórias que versem sobre honorários de sucumbência: considerações sobre admissibilidade e mérito. In: BEDAQUE, José Roberto dos Santos et al. (Coords.). Estudos de direito processual civil em homenagem ao Professor José Rogério Cruz e Tucci. Salvador: JusPodivm, 2018.

ARAÚJO, Fabio Caldas de. Curso de processo civil. Tomo I. São Paulo: Malheiros, 2016.

BEDAQUE, José Roberto dos Santos. Comentário ao art. 297, do CPC. In: SCARPINELLA BUENO, Cassio. (Coord.). Comentários ao Código de Processo Civil. Vol. 1. São Paulo: Saraiva, 2017.

CHIOVENDA, Giuseppe. Instituições de direito processual civil. 3. ed. Vol. III. Trad. J. Guimarães Menegale. São Paulo: Saraiva, 1969.

COSTA NETO, José Wellington Bezerra da. Assistência judiciária gratuita: acesso à justiça e carência econômica. Brasília: Gazeta Jurídica, 2013.

DINAMARCO, Cândido Rangel. Instituições de direito processual civil. 7. ed. Vol. II. São Paulo: Malheiros, 2017.

DINAMARCO, Cândido Rangel. Fundamentos do processo civil moderno. 6. ed. São Paulo: Malheiros, 2010. LA CHINA, Sergio. Manuale di diritto processuale civile. Vol. I. Milano: Giuffrè, 2003.

LEONEL, Ricardo de Barros. Ministério Público e despesas processuais no novo Código de Processo Civil. Revista de processo. São Paulo, ano 40, v. 249, p. 173-185, nov./2015.

LOPES, Bruno Vasconcelos Carrilho. Estabilização da tutela antecipada e coisa julgada. In: SCARPINELLA BUENO, Cassio. (Coord.). Tutela provisória no novo CPC. São Paulo: Saraiva, 2016.

LOPES, Bruno Vasconcelos Carrilho. Honorários advocatícios no processo civil. São Paulo: Saraiva, 2008.

LOPES, João Batista. Tutela antecipada no processo civil brasileiro. 5. ed. São Paulo: Editora Castro Lopes, 2016.

MARINONI, Luiz Guilherme. Tutela de urgência e tutela da evidência. 1. ed. São Paulo: RT, 2017.

PROTO PISANI, Andrea. Lezioni di diritto processuale civile. 5. ed. Napoli: Jovene, 2006.

SANTOS, Silas Silva. Honorários advocatícios. In: RODRIGUES, Daniel Colnago et al. (Orgs.). Processo civil contemporâneo: estudos em homenagem ao Professor Gelson Amaro de Souza. São Paulo: Lualri Editora, 2018, p. 550-568.

SANTOS, Silas Silva. Litisconsórcio eventual, alternativo e sucessivo. São Paulo: Atlas, 2013.

SCARPINELLA BUENO, Cassio. Curso sistematizado de direito processual civil. 9. ed. Vol. I. São Paulo: Saraiva, 2018.

SCARPINELLA BUENO, Cassio. Honorários advocatícios e o art. 85 do CPC de 2015: reflexões em homenagem ao professor José Rogério Cruz e Tucci. In: BEDAQUE, José Roberto dos Santos et al. (Coord.). Estudos de direito processual civil em homenagem ao Professor José Rogério Cruz e Tucci. Salvador: JusPodivm, 2018.

SICA, Heitor Vitor Mendonça. Doze problemas e onze soluções quanto à chamada "estabilização da tutela antecipada". In: SCARPINELLA BUENO, Cassio. (Coord.). Tutela provisória no novo CPC. São Paulo: Saraiva, 2016. 
SILVA, Rodrigo da Guia. Enriquecimento sem causa: as obrigações restituitórias no direito civil. São Paulo: RT, 2018.

TALAMINI, Eduardo. Tutela de urgência no projeto de novo Código de Processo Civil: a estabilização da medida urgente e a "monitorização" do processo civil brasileiro. Revista de processo, São Paulo, ano 37, v. 209 , n. 8, p. 24-25, jul./2012.

Recebido em: 11/03/2020

Aprovado em: 13/04/2021

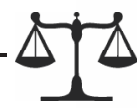

